given at the end of each part, and there is a bibliography of books of a more comprehensive nature on antibiotics and cognate subjects.

The speed at which this subject is growing is shown by the fact that although this book bears the publication date 1949, there is an appendix of twelve linesa sort of stop-press paragraph-on the two latest antibiotics of clinical importance, chloromycetin and aureomycin. One wonders whether either or both of these substances will not in future editions of this book come to deserve as much notice as any of the antibigtics mentioned in the present edition.

Tour ${ }^{\prime}$ the Continent, 1765

By Thomas Pennant. Fdited with Notes by G. R. de Beer. (Ray Society 132 for 1947.) Pp. xii+ $178+9$ plates. (Ifogon: Bernard Quaritch, Ltd., 1948.) 17s. $6 d$.

TT was a happy Ydea of the president of the Ray Society, Pro. G. R. de Beer, to edit this work. He has alr dy written extensively and with authority on ceftain European travellers, and he wisely allows Pennat $t^{\prime}$ to tell his own story without cumbering the narratide with a number of notes. With the help of Mr. A. C. Townsend, he has identified the most important people referred to in the narrative.

Pennant's tour is of great interest as a journey across Europe. He followed a route "not very dissimilar from that which would be adopted by a road user of to-day"; but he managed to see everything of interest and to note facts of the greatest value. The manufacture of looking-glasses in Paris, the migration of peasants from Savoy to Burgundy and other parts of France, the variety of plants on Mt. Saleve, the fish in the Lake of Geneva, "the snowy Alps, craggy and wooded with fir", the trade in drugs in Nuremberg, the best collection of pictures in Europe at Dusseldorf, the "vast pile" of East India House at Amsterdam - such is the variety and wealth of his observations.

No less important-perhaps more so-is his record of meetings with great men, including Voltaire "as meagre and as arid a figure as ever I saw". Yet his eyes "the most brilliant I ever saw sparkled with pleasure at the attention paid to his frame", and his conversation"the whole time extremely lively". The only end to the good things in this book is the last page. if

J. N. L. B.

The Coast of Northeast Greenland

With Hydrographie Studies im the Greenland Sea. (The Louise A. Boyd) Arch Expeditions of 1937 and 1938.) By Lquise Whoyd; with Contributions by Richard Fo te Eint, Tamean. LeRoy, Henry J. Oosting Fred A. Bull F. Eyolf Bronner, A. J. HAlfe ty Alice Eastwobd and the United States Coast afd Heodetic Survey. (American Geographical Sdciety, Special Publication No. 30.) Pp. xii $+339+$ 12 plates. (New York: American Geographical Society, 1948.) 6 dollars.

$7 \mathrm{HE}$ Arctic expeditions of 1937 and 1938 organised and financed by Miss Louise Boyd were sequels to previous expeditions on the east coast of Greenland and carried her surveys and geological work as far north as lat. $78^{\circ}$. Owing to war conditions and possible enemy use of this coast, the publication of the work was withheld until recently. Like all her publications, this work is superbly illustrated by well-chosen pictures that portray in a striking way the geomorphology of that coast. The narrative of the expedition is by Miss Poyd; but the geological contributions are by R. F. Flint, F. E. Bronner and others. There are also some technical papers, including a noteworthy ecological one by $\mathrm{H}$. J. Oosting and a paper on the sonic sounding by J. LeRoy. A separate portfolio contains panoramic views and a number of maps, including a large-scale bathymetric map of the Greenland Sea, and another along the East Greenland coast. The work is a valuable contribution, not merely to the knowledge of the East Greenland coast but also to glacial geology in general.

Man's Conquest of Nature

By Dr. F. Sherwood Taylor. (Life and Leisure Series, No. 5.) Pp. 116. (London: Paul Elek (Publishers), Ltd., 1948.) 7s. 6d. net.

HIS little book describes admirably the steps in man's gedual conquest of Nature, that is to say, throans by which he has acquired mastery over the forces of Nature and used them, and the spostances of the crust of the earth, to gain his material ends. A beginning was made with the development of the crafts and, not least among them, the art of writing. Then came the Greek contribution, the application of thought and reasoning to the phenomena of Nature, and later, the realization that for further progress in our knowledge of the universe and control over its forces, reasoning and deduction must be based on accurate observations and measurement. It is the story of the growth of natural science by experiment, and of the use by man of power, derived ultimately from the energy of the sun, of materials and machinery to improve his lot; to assist him in his war-to use Dr. Sherwood Taylor's chapter headings-against poverty, against distance and against death.

The war against man's own nature is left to a final chapter, which is all too short, for there is much for reflexion in the author's observation : "It may be thought, then, that man is happiest when his degree of conquest of Nature is duly proportioned to his degree of conquest of his own mental nature". One could wish that he had enlarged on this theme; for the events of the age in which we live have forced upon us the realization that man's control of natural forces has raised moral issues which transcend all others in importance.

\section{An Outline of the Development of Science}

By Mansel Davies. (Thinker's Library, No. 120.) Pp. vii $+214+16$ płates. (London: Watts and Co., Ltd., 1948.) 3s. s. net.

TO cofdense, into a little volume of two hundred 1 pages an account of the origins and develop. monf of science from the earliest times to the present day is a formidable undertaking, and yet Dr. Mansel Davies has succeeded admirably in his task. The book is written for the layman, and if, on reading parts of the story with which one has some special familiarity, they seem tantalizingly brief and perhaps over-simplified, one gets to the end with the impression that the author has, after all, accomplished his object without any sacrifice of accuracy; he has given in simple terms an outline of the growth of science and an indication of the meaning of scientific work and the nature of scientific research which may serve as a guide and a stimulus for further inquiry. Technicalities are avoided. The work has a historical and biographical thread, and is at its best in its brief sketches of the contribution of each worker to his subject.
T. M. 